\title{
透析症例のかゆみに対するテルフェナジンの効果
}

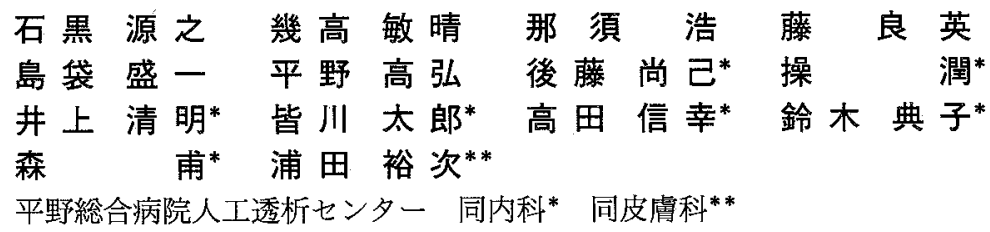

key words：テルフェナジン, かゆみ, 血液透析, CAPD

〈要旨〉

慢性腎不全のため透析を施行している症例で, 瘦痒感を訴えている 20 例（男 6 例，女 14 例，平均年齢 $58 \pm 13$ 歳， 平均透析年数 $3.2 \pm 2.5$ 年）に対し，テルフェナジン $120 \mathrm{mg} /$ 日分 2 を 4 週間投与し，投与前後で瘙痒感，IgE に関 して検討した。痋痒感は有意 $(p<0.001)$ に改善した。有効率 $80 \%$, 安全度 $100 \%$, 有用度 $80 \%$ あっあた。 IgEは有 意な変動を認めなかった。透析症例における非透析日の主要代謝物の $\mathrm{C}_{\max }$ は $654.4 \pm 250.6 \mathrm{ng} / \mathrm{m} / \mathrm{t}_{\max } 3.4 \pm 0.5$ 時間, $\mathrm{t}_{1 / 2} 5.1 \pm 1.6$ 時間, $\mathrm{AUC}_{0 \sim 24} 6,917 \pm 3,519 \mathrm{ng} \cdot \mathrm{hr} / \mathrm{ml}$ であった。透析症例における透析日の主要代謝物の $\mathrm{C}_{\max }$ は $670.5 \pm 124.5 \mathrm{ng} / \mathrm{ml}_{l} \mathrm{t}_{\max } 4.3 \pm 0.2$ 時間, $\mathrm{t}_{1 / 2} 5.8 \pm 0.8$ 時間, $\mathrm{AUC}_{0 \sim 24} 7,421 \pm 2,236 \mathrm{ng}$ ・ hr/ml であった。透 析によるテルフェナジンクリアランスは $20 \mathrm{~m} l / \mathrm{min}$ であった. CAPD 症例における主要代謝物の $\mathrm{C}_{\max }$ は $508.9 \pm$ $60.2 \mathrm{ng} / \mathrm{m} l, t_{\max } 6.2 \pm 1.5$ 時間, $\mathrm{t}_{1 / 2} 6.7 \pm 0.6$ 時間, $\mathrm{AUC}_{0 \sim 24} 6,767 \pm 171 \mathrm{ng} \cdot \mathrm{hr} / \mathrm{ml}$ であった. 以上の結果により 抗アレルギー剂テルフェナジン（トリルダン®）は，透析症例の皮膚瘙痒感に対しても有用であると示唆された。腎 不全症例では $\mathrm{C}_{\max }, \mathrm{AUC}_{0 \sim 24}$ が高值のため投与量の減量も考慮する必要があろう.

\section{Effect of terfenadine on uremic itching in dialysis patients}

Motoyuki Ishiguro, Toshiharu Ikutaka, Hiroshi Nasu, Ryoei Fuji, Seiichi Shimabukuro, Takahiro Hirano, Naoki Goto*, Jun Misao*, Kiyoaki Inoue*, Taro Minagawa*, Nobuyuki Takada*, Noriko Suzuki*, Hajime Mori*, Yuji Urata**

Hemodialysis Center, Department of Internal Medicine*, Department of Dermatology**, Hirano General Hospital

Twenty patients ( 6 males and 14 females, mean age $58 \pm 13$ years) with chronic renal insufficiency and who had been an dialysis for an average of $3.2 \pm 2.5$ years complained of itchiness. They were treated with Terfenadine (TRILUDAN®) at a daily dosage of $120 \mathrm{mg}$ (given in two divided doses) for four weeks. An assessment of changes in itchiness and IgE before and after treatment was made.

Itchiness improved significantly $(p<0.001)$. The improvement ratio was $80 \%$, the safety ratio was $100 \%$, and the usefulness ratio $80 \%$. However, IgE showed no significant changes. Major metabolic of Terfenadine $\left(M_{1}\right)$ in the patients had a $C_{\max }$ of $654.4 \pm 250.6 \mathrm{ng} / \mathrm{ml} \mathrm{t}_{\max }$ of $3.4 \pm 0.5 \mathrm{hr}, \mathrm{t}_{1 / 2}$ of $5.1 \pm 1.6 \mathrm{hr}$, and $A U \mathrm{C}_{0 \sim 24}$ of $6,917 \pm$ $3,519 \mathrm{ng} \cdot \mathrm{hr} / \mathrm{m} l$ on non-dialysis days. On dialysis days, the $C_{\max }$ was $670.5 \pm 124.5 \mathrm{ng} / \mathrm{m} / \mathrm{t}_{\max } 4.3 \pm 0.2 \mathrm{hr}, \mathrm{t}_{1 / 2}$ $5.8 \pm 0.8 \mathrm{hr}$, and $A_{U C C_{0 \sim 24}} 7,421 \pm 2,236 \mathrm{ng} \cdot \mathrm{hr} / \mathrm{ml}$. Terfenadine clearance by dialysis was $20 \mathrm{~m} / / \mathrm{min}$. Patients on CAPD showed a $C_{\max }$ of $508.9 \pm 60.2 \mathrm{ng} / \mathrm{m} / \mathrm{t}_{\max }$ of $6.2 \pm 1.5 \mathrm{hr}, \mathrm{t}_{1 / 2}$ of $6.7 \pm 0.6 \mathrm{hr}$, and AUC $_{0 \sim 24}$ of $6,767 \pm 171$ $\mathrm{ng} \cdot \mathrm{hr} / \mathrm{ml}$

The above results suggest that Terfenadine, an antiallergic agent, is useful in treating itching skin in patients on dialysis. It is necessary to consider lower doses since patients with renal insufficiency had higher $\mathrm{C}_{\max }$ and $\mathrm{AUC}_{0 \sim 24}$ values.

石黒 源之 平野総合病院人工透析センター $=501-11$ 岐阜市黒野 $176(0582-39-2325)$

〔受付：平成 4 年 1 月 13 日, 受理 : 平成 4 年 7 月 14 日〕 


\section{緒言}

血液透析を受けている㭧者では，種々の皮膚異常を合 併している例が多くみられ，とくに皮膚瘙㾕症は全体の 7 割以上に認められる頻度の高い合併症である。これら の皮膚異常の原因は，今日もなお一元的に説明できず， 従って未だに有用な治療法は確立していない現状であ る。重要な事実は, 痒みは患者にとってしばしば耐光切 れないほどになり，その心理的平衡をも危機に落し入れ てしまうことである。この理由から，痒みの症状の治療 法を実現できるのは時機を得を研究であると考え，この 目的のために，我々は新しい抗アレルギー剤，テルフェ ナジンの効果を試みることを思いついたのである。この 薬物には実際, 中枢神経系に対する副作用はなく ${ }^{1 \sim 4)}$, 長 期の治療に用いても耐性は良好であり 胆汁中に排泄されるので，透析患者の体内での薬物動態 からみても好適である5).

著者らは，1990 年から 1991 年に慢性腎不全のため透 析を受けている患者のうち皮虔痋痒を訴える症例に抗ア レルギー戍テルフェナジン（トリルダン®）を投与し， 皮膚癌痒症に対する効果と血液透析患者と CAPD 患者 におけるテルフェナジンの血漿中動態をカルボン酸型代
1) 透析効率 $($ 各 $n=3)$

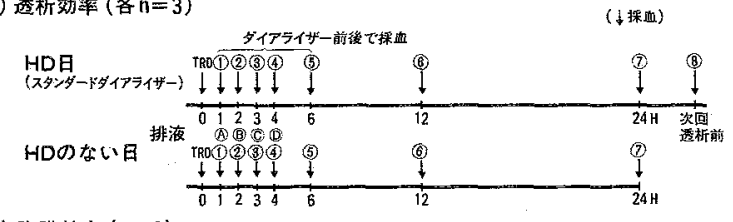

2) 腹膜効率 $(n=3)$

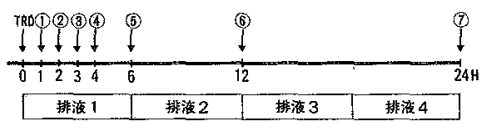

図 1 血中および排液濃度の測定

謝物を測定することにより検討したので報告する。

\section{対象と方法}

1. 血漿中濃度と排液中濃度の検討

透析症例 $(n=3)$ の透析日と非透析日, CAPD 症例 $(\mathrm{n}=3)$ に扔いてテルフェナジンの血漿中濃度の推移, 透析効率，排液中濃度を検討した。各採血時間带，腹膜 透析液貯留時間は図 1 のごとくである。血漿中濃度，排 液中濃度は HPLC 法で, 薬理活性を有するカルボン酸型 代謝物を測定した。対象例㹥全症例インフォームドコン セントを得ている。

表 1 患者背景

\begin{tabular}{|c|c|c|c|c|c|}
\hline 略 名 & 年 & 性 & 基礎疾患 & $\mathrm{HD}$ 年数 & 併 \\
\hline 1 & 65 & M & 慢性系球体腎炎 & 5 & $\begin{array}{l}\text { シグマート } 3 \mathrm{~T}, ノ \text { ノノン } 3 \mathrm{~T}, \text { アミュー7.5, ユリノーム } 2 \mathrm{~T}, \text { グランダキ } \\
\text { シン } 3 \mathrm{~T}\end{array}$ \\
\hline 2 & 76 & $\mathrm{~F}$ & $n$ & 4 & エラスチーム $3 \mathrm{~T}$, ZベラNソフト $3 \mathrm{C}$, マーズレン $\mathrm{S} 2.0$, セロケン $3 \mathrm{~T}$ \\
\hline 3 & 45 & $\mathrm{~F}$ & $n$ & 2 & コランチル 3.0, スムリン $6 \mathrm{~T}$, ニバジール $2 \mathrm{~T}$ ，ガストロピロール 2.0 \\
\hline 4 & 67 & $\mathrm{~F}$ & $n$ & 1 & セルベックス $3 \mathrm{C}$, カマ 2.0, エンテロノン $\mathrm{R} 2.0$, ラシックス $1 \mathrm{~T}$ \\
\hline 5 & 53 & $\mathrm{~F}$ & $\|$ & 10 & ロカルトロール1 C,フルイトラン $1 \mathrm{~T}$, ケーキサレート $5 \mathrm{~g}$, チオデロン $3 \mathrm{C}$ \\
\hline 6 & 45 & M & $n$ & 1 & テオロング $2 \mathrm{~T}$ ，アダラートL $\mathrm{L}(20) 2 \mathrm{~T} ，$ フォイパン $6 \mathrm{~T}$ ，カブトリル $3 \mathrm{~T}$ \\
\hline 7 & 43 & $\mathrm{~F}$ & $\eta$ & 1 & ラシックス $1 \mathrm{~T}$, コメリアン $3 \mathrm{~T}$, アンギナール $3 \mathrm{~T}$, セルペックス 1.5 \\
\hline 8 & 41 & $\mathrm{~F}$ & $n$ & 5 & ムコソルバン $2 \mathrm{~T}$, ニバジール $2 \mathrm{~T}$, チアトン $3 \mathrm{C}$, セルベックス 1.5 \\
\hline 9 & 56 & $\mathrm{~F}$ & " & 4 & ネオユモール 2.0 , セレキノン $3 \mathrm{~T}$, チオデロン $3 \mathrm{C}$ ，ケーキサレート $5 \mathrm{~g}$ \\
\hline 10 & 75 & $\mathrm{~F}$ & 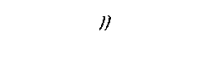 & 1 & $\begin{array}{l}\text { ペルジピン LA }(20) 2 \mathrm{C}, \text { ザンタック } 2 \mathrm{~T}, \text { アルドメット } 2 \mathrm{~T},=\text { トール } \mathrm{R} 2 \mathrm{C}, \\
\text { ウルグート } 3 \mathrm{C}\end{array}$ \\
\hline 11 & 69 & M & $n$ & 3 & エパデール 6 C，ガスター3 T, セレキノン $3 \mathrm{~T}$, ロカルトロール $1 \mathrm{C}$ \\
\hline 12 & 70 & $\mathrm{~F}$ & $m$ & 6 & なし \\
\hline 13 & 59 & $\mathrm{~F}$ & 11 & 1 & プレタール $(100) 2 \mathrm{~T}$ \\
\hline 14 & 70 & $\mathrm{~F}$ & 糖尿病 & 1 & プレスモード $2 \mathrm{~T}$, メインテート $1 \mathrm{~T}$, アルドメッド $2 \mathrm{~T}$, カルスロット $1 \mathrm{~T}$ \\
\hline 15 & 55 & M & " & 3 & $\begin{array}{l}\text { アルタット } 2 \mathrm{C}, \text { シグマート } 3 \mathrm{~T}, \text { メトリジン } 2 \mathrm{~T}, \text { エパデール } 6 \mathrm{C}, \text { スムリ } \\
\text { ン } 3 \mathrm{~T}\end{array}$ \\
\hline 16 & 72 & M & $n$ & 2 & ノイロビタン $2 \mathrm{~T}$, スムリン $6 \mathrm{~T}$, シナール $3 \mathrm{~T}$ ，バリターゼオーラル $3 \mathrm{~T}$ \\
\hline 17 & 71 & M & $n$ & 3 & $\begin{array}{l}\text { ラシックス } 1 \mathrm{~T}, \text { ダオニール } 1 \mathrm{~T} \text {, エパデール } 6 \mathrm{C} \text {, フォルセニド } 3 \mathrm{~T}, \text { 口コ } \\
\text { ルナール } 3 \mathrm{~T}\end{array}$ \\
\hline 18 & 59 & $\mathrm{~F}$ & $n$ & 2 & $\begin{array}{l}\text { ワンアルファ }(0.5) 1 \mathrm{~T}, \text { ラシックス } 1 \mathrm{~T}, \text { テシプール } 2 \mathrm{~T}, \text { アダラート L }(20) \\
2 \mathrm{~T}, \text { ニトール R } 2 \mathrm{C}\end{array}$ \\
\hline 19 & 29 & $\mathrm{~F}$ & SLE & 8 & $\begin{array}{l}\text { ロカルトロール } 2 \mathrm{C}, \text { タガメット } 3 \mathrm{~T} \text {, エラスチーム } 3 \mathrm{~T} \text {, セロケン } 3 \mathrm{~T} \text {, フ } \\
\text { オイパン } 6 \mathrm{~T}\end{array}$ \\
\hline 20 & 51 & $\mathrm{~F}$ & アミロイドーシス & 2 & $\begin{array}{l}\text { ノイロトロピン } 2 \mathrm{~T} \text {, アルタット } 1 \mathrm{C} \text {, カマ } 1.5 \text {, テシプール } 2 \mathrm{~T} \text {, セルベック } \\
\text { ス } 3 \mathrm{C}\end{array}$ \\
\hline mean $\pm S D$ & $58 \pm 13$ & & & $3.2 \pm 2.5$ & \\
\hline
\end{tabular}


表 2 白取の分類。痒みの程度表

\begin{tabular}{|c|c|c|}
\hline 程 度 & 日中の症状 & 夜間の症状 \\
\hline 4。(激烈な痒み) & 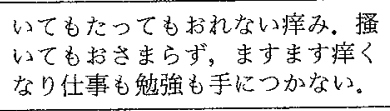 & $\begin{array}{l}\text { 痒くてほとんど眠れず，しょっちゅう } \\
\text { 搔いているが，盗くとますます㾕みが } \\
\text { 強くなる. }\end{array}$ \\
\hline 3.（中等度の痒み） & $\begin{array}{l}\text { かなり痒く, 人前でも搔く.痒み } \\
\text { のためイライラし，たえず搔いて } \\
\text { いる。 }\end{array}$ & $\begin{array}{l}\text { 痒くて目がさぬる。ひと搔きすると一 } \\
\text { 応眠るが, 無意識のうちに眠りながら } \\
\text { 搔く. }\end{array}$ \\
\hline 2、（軽度な痒み） & $\begin{array}{l}\text { 時に手が们き, 軽く掻く程度で一 } \\
\text { 応おさまり,あまり気にならない. }\end{array}$ & $\begin{array}{l}\text { 多少痒みはあるが，搔けばおさまる。 } \\
\text { 㾕みのために目がさめることはない。 }\end{array}$ \\
\hline 1.（軽微な痒み） & $\begin{array}{l}\text { 時にむずむずするが，特に搔かな } \\
\text { くても我慢できる. }\end{array}$ & $\begin{array}{l}\text { 就寝時少ずかに痒いが, 特に意識して } \\
\text { 搔くほどでない.よく眠れる. }\end{array}$ \\
\hline 0 。（症状なし） & $\begin{array}{l}\text { ほとんどあるいはまったく痒みを } \\
\text { 感じない. }\end{array}$ & $\begin{array}{l}\text { ほとんどあるいはまったく痒みを感じ } \\
\text { ない. }\end{array}$ \\
\hline
\end{tabular}

表 3 当センタ-の瘙痒感の判定基準

6 度: 激烈な瘙痒感

5 度：序詳感強度

4 度: 瘦㾕感中等度

3 度: 透析後半・終了時に限られた中等度瘤痒感

2 度: 瘦痒感軽度

1 度: 疼痒感 $( \pm)$

0 度：痋痒感なし

個々の症例において，自己がどの度数に匹敵するか主 観的に選択してもらう。

\section{2。臨床応用}

㿋痒を訴える慢性透析症例 $(\mathrm{n}=20)$ に対し, テルフェ ナジン投与前，1 1 か月後でその効果，投与前後での $\operatorname{IgE}$ の変動を検討した。

\section{対象患者}

血液透析施行中で, かつ疰痒を示す患者 20 例 (男性 6 例, 女性 14 例, 平均年齢 $58 \pm 13$ 歳, 平均透析年数 $3.2 \pm$ 2.5 年，表 1 )。

除外患者

\section{1） 14 歳以下の患者}

2 ) 妊婦，妊娠している可能性のある患者および授乳 中の患者

3) 重篤な心，肝疾患を合併する患者

4 ）担当医が不適当と判断した患者

試験方法

1) 投与方法

テルフェナジン（トリルダン®） $60 \mathrm{mg}$ 錠 1 回 1 錠 1 日 2 回朝食後预よび夕食後に投与。

2) 併用薬剂

原則として試験期間中はテルフェナジン（トリルダ ン®）錠以外の止㾕効果が期待される薬剤（他の抗アレ ルギー剤，抗ヒスタミン剂など）の併用は行わなかった。
3) 透析条件：試験開始前 3 加月以上より試験終了ま でダイアライザ一の変更はなし, その他の透析条件も不 変。

4) 試験期間： 4 週間以上。

評価項目

1) 櫁㾕

重症度は白取の基準（表 2）と当透析センターの基準 （表 3）の 2 法で判定した。

2 ) 最終囑痒改善度

効果判定は投与前と投与 1 か月後に行った.

瘙痒症に対する有効率の評価は，患者の瘙痒感を自覚 的に当センター基準で 7 段階に分類した。 1 段階の改善 をやや有効，2段階の改善を有効，3段階以上の改善を 著効と評価した. 本剂投与前の判定は対象の 20 例中， 6 度が 1 例， 5 度が 3 例， 4 度が 13 例， 3 度が 3 例， 2 度 が 0 例, 1 度が 0 例， 0 度が 0 例で, 平均度数は $4.1 \pm 0.7$ (Mean士SD) であった。

さらに白取の分類を用い，投与前と 1 か月後で評価し た。1段階の改善をやや有効，2段階以上の改善を有効 とした。本剤投与前の判定は対象 20 例中， 4 度が 1 例， 3 度が 15 例， 2 度が 4 例， 1 度が 0 例， 0 度が 0 例で平 均度数は $2.8 \pm 0.4$ (Mean士SD) であった。

痹痒症に対する最終有効率の判定は前記の当センター 基準を用いて判定した。

3) 安全度

試験期間中に発現した副作用の有無などから以下の 4 段階で判定した。

1 : 問題なし 2 :やや問題あり $3:$ かなり問題 あり 4 : 問題あり

4 ）有用度

最終蛮痒有効率と安全度を総合的に判定して以下の 6 段階で評価した。 

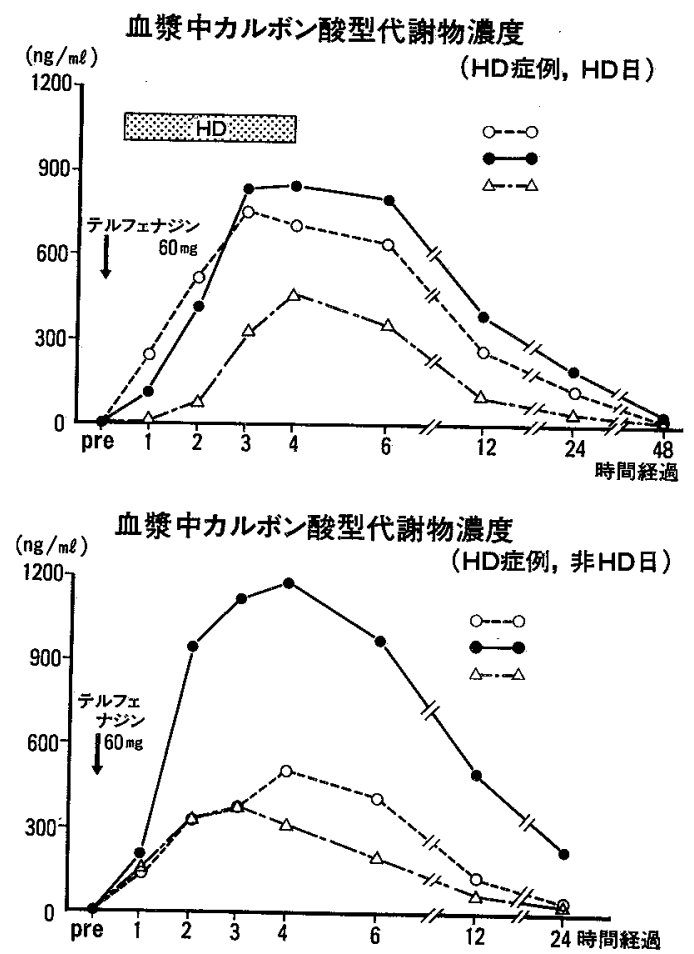

図 2 透析日, 非透析日のテルフェナジン薬物動 態
HD施行時排液中カルボン酸型代謝物濃度
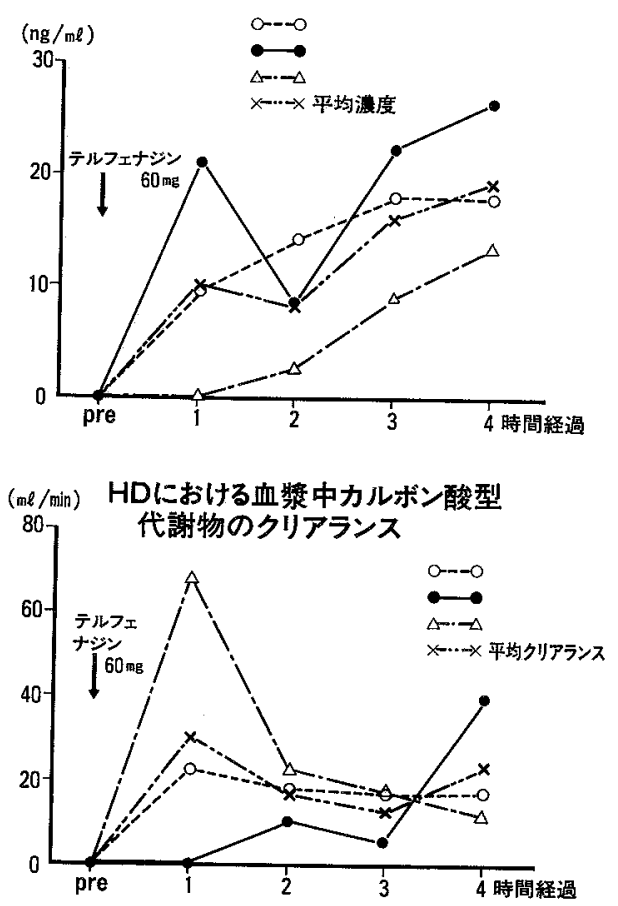

図 3 血液透析によるテルフェナジンのクリアラ ンス

表 4 テルフェナジン $60 \mathrm{mg}$ 単回投与に抒けるカルボン酸型代謝物の薬動力学的 パラメー夕

\begin{tabular}{l|c|c|c}
\hline & 非透析日 & 透析日 & CAPD \\
\hline $\begin{array}{l}\mathrm{c}_{\max }(\mathrm{ng} / \mathrm{m} l) \\
\text { 最高血漿中濃度 }\end{array}$ & $654.4 \pm 250.6$ & $670.5 \pm 124.5$ & $508.9 \pm 60.2$ \\
\hline $\begin{array}{l}\mathrm{t}_{\max } \text { (時間) } \\
\text { 最高血漿中濃度到達時間 }\end{array}$ & $3.4 \pm 0.5$ & $4.3 \pm 0.2$ & $6.2 \pm 1.5$ \\
\hline $\begin{array}{l}\mathrm{t}_{12} \text { (時間) } \\
\text { 消失半隇期 }\end{array}$ & $5.1 \pm 1.6$ & $5.8 \pm 0.8$ & $6.7 \pm 0.6$ \\
\hline $\begin{array}{l}\mathrm{AUC} 0 \sim 24 \mathrm{ng} \cdot \mathrm{hr} / \mathrm{m} l \\
\text { 血漿中濃度時間曲線下面積 }\end{array}$ & $6,917 \pm 3,519$ & $7,421 \pm 2,236$ & $6,767 \pm 171$ \\
\hline
\end{tabular}

1 : 極めて有用 2 : 有用 $3:$ やや有用 4 : 有 用でない 5 ：好ましくない 6 : 判定不能

\section{結果}

1。透析症例に抢ける血獎中濃度の推移

非透析日の服用による血漿中カルボン酸型代謝物濃度 の最高濃度は $\mathrm{C}_{\max } 654.4 \pm 250.6 \mathrm{ng} / \mathrm{m} l$ と，健常成人に よるデー夕の最高濃度 $300 \mathrm{ng} / \mathrm{m} l(\mathrm{n}=7)$ より高かった。 さらに最高濃度にいたる時間, $\mathrm{t}_{\max }$ は健常成人の 2.3 時 間に対して $3.4 \pm 0.5$ 時間と遅れを認めた。消失半減期 $\mathrm{t}_{1 / 2}$ は $5.1 \pm 1.6$ 時間, 血獎中濃度時間曲線下面積 $\mathrm{AUC}_{0 \sim 24}$ は $6,917 \pm 3,519 \mathrm{ng} \cdot \mathrm{hr} / \mathrm{m} l$ であった。
透析前に服用した場合の最高濃度は $\mathrm{C}_{\max }$ は $670.5 \pm$ $124.5 \mathrm{ng} / \mathrm{m} l$, 最高濃度にいたる時間 $t_{\max }$ は $4.3 \pm 0.2$ 時 間であり, 消失半減期 $\mathrm{t}_{1 / 2}$ は $5.8 \pm 0.8$ 時間, 血漿中濃度 時間曲線下面積 $\mathrm{AUC}_{0 \sim 24}$ は 7,421 $22,236 \mathrm{ng} \cdot \mathrm{hr} / \mathrm{m} l$ て あった（図 2，表 4 ）。

透析施行時の排液中カルボン酸型代謝物濃度は, 血漿 中濃度の上昇とともに経時的に上昇し, 透析終了時に約 $20 \mathrm{ng} / \mathrm{m} l$ となった。透析に扔ける血漿中カルボン酸型代 謝物のクリアランスは経過中約 $20 \mathrm{~m} l / \mathrm{min}$ と安定して いた（図 3 ，表 4). 

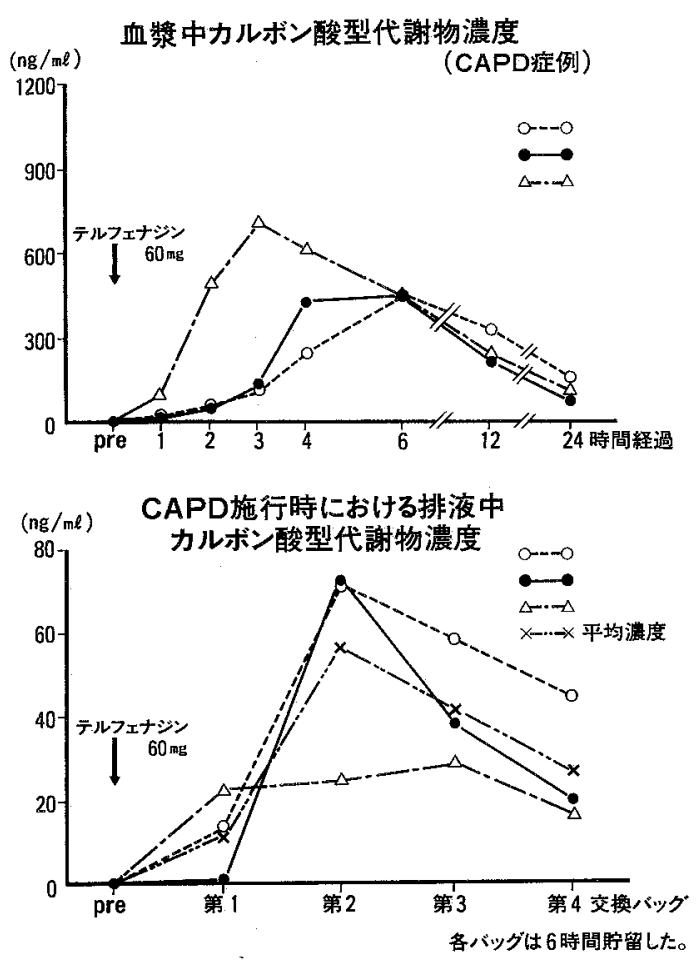

図 4 CAPD 症例におけるテルフェナジン薬物 動態
2. CAPD 症例における血漿中濃度の推移

CAPD 症例における血墏中カルボン酸型代謝物の最 高濃度 $\mathrm{C}_{\max }$ は $508.9 \pm 60.2 \mathrm{ng} / \mathrm{m} l$ と健常成人の最高濃 度 $300 \mathrm{ng} / \mathrm{m} l$ より高かった。さらに最高濃度に至る時間 $t_{\max }$ は, $6.2 \pm 1.5$ 時間と遅れを認めた。消失半減期 $\mathrm{t}_{1 / 2}$ は $6.7 \pm 0.6$ 時間, 血墏中濃度時間曲線下面積 $\mathrm{AUC}_{0 \sim 24}$ は $6,767 \pm 171 \mathrm{ng} \cdot \mathrm{hr} / \mathrm{m} l$ であった。

CAPD 施行時における排液中カルボン酸型代謝物濃 度は，第 1 バッグ(内服から内服後 6 時間)より第 2 バッ グ(内服後 6 時間目から 12 時間目まで)が高い值を示し， 第 3 バッグ，第 4 バッグと減少したが，第 4 バッグでも 20 〜 $50 \mathrm{ng} / \mathrm{m} l$ とかなりの濃度を示した（図 4 ，表 4 ）。

\section{3 . 瘙痒感の変動}

投与前の痋痒感度数は日取の分類で $2.8 \pm 0.4(\mathrm{n}=$ $20)$ ，投与 4 週目には $1.5 \pm 0.8(n=20)$ と有意 $(\mathrm{p}<$ $0.001)$ に改善した。本院の分類で投与前の疰痒感度数は $4.1 \pm 0.7(\mathrm{n}=20)$ ，投与 4 週目には 2.2士1.4（ $\mathrm{n}=20 ）$ と有意 $(\mathrm{p}<0.001)$ に改善した（表 5$)$.

最終癔痒有効率は，著効 $8 / 20$ 例 $40 \%$ ，有効 $3 / 20$ 例 $15 \%$, やや有効 $5 / 20$ 例 $25 \%$, 不変 $4 / 20$ 例 $25 \%$, 増悪 $0 /$ 20 例 $0 \%$ であった。

安全度は問題なし $20 / 20$ 例 $100 \%$ ，やや問題あり $0 / 20$ 例 $0 \%$ ，かなり問題あり $0 / 20$ 例 $0 \%$ ，問題あり $0 / 20$ 例

表 5 臨床結果

\begin{tabular}{|c|c|c|c|c|c|c|c|c|}
\hline \multirow{2}{*}{ 略 名 } & \multicolumn{3}{|c|}{ 白取の痒み点数 } & \multicolumn{3}{|c|}{ 石黒の痒み点数 } & \multicolumn{2}{|c|}{$\operatorname{IgE}$} \\
\hline & 前 & 4 週後 & 4 週一前 & 前 & 4週後 & 4 週一前 & 投与前 & 投与後 \\
\hline 1 & 3 & 1 & 2 & 4 & 1 & 3 & $10>$ & $10>$ \\
\hline 2 & 3 & 2 & 1 & 4 & 3 & 1 & $10>$ & $10>$ \\
\hline 3 & 3 & 0 & 3 & 4 & 0 & 4 & $10>$ & $10>$ \\
\hline 4 & 3 & 1 & 2 & 4 & 2 & 2 & 82 & 73 \\
\hline 5 & 2 & 1 & 1 & 4 & 1 & 3 & $10>$ & $10>$ \\
\hline 6 & 3 & 1 & 2 & 4 & 1 & 3 & 51 & 52 \\
\hline 7 & 3 & 2 & 1 & 4 & 3 & 1 & 50 & 79 \\
\hline 8 & 3 & 0 & 3 & 4 & 0 & 4 & 257 & 196 \\
\hline 9 & 3 & 2 & 1 & 4 & 4 & 0 & 40 & 30 \\
\hline 10 & 2 & 2 & 0 & 3 & 3 & 0 & 14 & $10>$ \\
\hline 11 & 3 & 1 & 2 & 5 & 2 & 3 & 32 & 46 \\
\hline 12 & 2 & 1 & 1 & 3 & 1 & 2 & 27 & 19 \\
\hline 13 & 3 & 2 & 1 & 5 & 4 & 1 & 64 & 40 \\
\hline 14 & 2 & 2 & 0 & 3 & 3 & 0 & 185 & 159 \\
\hline 15 & 3 & 2 & 1 & 4 & 2 & 2 & I & $\nearrow$ \\
\hline 16 & 3 & 1 & 2 & 4 & 2 & 2 & 46 & 39 \\
\hline 17 & 3 & 1 & 2 & 4 & 1 & 3 & 2,880 & 3,090 \\
\hline 18 & 3 & 3 & 0 & 5 & 5 & 0 & 11 & $10>$ \\
\hline 19 & 3 & 3 & 0 & 4 & 4 & 0 & 11 & 16 \\
\hline 20 & 4 & 3 & 1 & 6 & 3 & 3 & 14 & 31 \\
\hline \multirow[t]{2}{*}{ mean $\pm \mathrm{SD}$} & $2.8 \pm 0$. & $1.5 \pm 0.8$ & $1.3 \pm 0.9$ & $4.1 \pm 0$. & $2.2 \pm 1.4$ & $1.8 \pm 1.3$ & $200 \pm 652$ & $207 \pm 700$ \\
\hline & \multicolumn{3}{|c|}{$\mathrm{p}<0.001$} & \multicolumn{3}{|c|}{$\mathrm{p}<0.001$} & \multicolumn{2}{|c|}{ NS } \\
\hline
\end{tabular}


有效率 $(n=20)$

0

\begin{tabular}{|c|c|c|}
\hline & $1 \leftarrow-20 \%$ & \\
\hline $\begin{array}{c}\text { 不変 } \\
\text { (4例 20\%) }\end{array}$ & 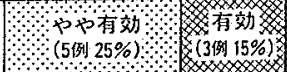 & 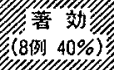 \\
\hline
\end{tabular}

安全度 $(n=20)$

問題なし（20例 100\%）

\begin{tabular}{|c|c|c|c|}
\hline 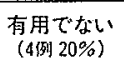 & ऐ中伤 $20 \%$ & 将 & 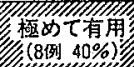 \\
\hline
\end{tabular}

図 5 テルフェナジンの有効率, 安全度, 有用度

0\%であった。

有用度以極女て有用 $8 / 20$ 例 $40 \%$, 有用 $4 / 20$ 例 $20 \%$, やや有用 $4 / 20$ 例 $20 \%$, 有用でない $4 / 20$ 例 $20 \%$, 好まし くない $0 / 20$ 例 $0 \%$, 判定不能 $0 / 20$ 例 $0 \%$ あった（図 $5)$.

\section{考察}

透析患者では種々の皮膚異常が高率に合併する。頻度 的には皮膚瘙痒症, 乾燥, 爪変化, 発汗障害, 色素沈着, 皮膚菱縮の順に認められている。皮膚癌痒症は透析症例 の 7 割以上に認められる頻度の高い合併症である。当透 析センターでも $67 \%$ の症例から痹痒症に対する対策を 求められている。慢性腎不全で透析中の症例では, しば しば乾皮症を伴ったかゆみのあることは古くより知られ ていた。笛の発生頻度は 10〜15\%といわれていたが，透 析が行われるようになってから，かゆみの頻度は著しく 増加している。これは透析により長期延命の症例が増え た結果であろう。一般に保存期慢性腎不全の際のからみ は腎障害の重症度と相関しているといわれるが，透析を 行っても必ずしも改善されない.また，性別，年齢，人 種とは関係がないとも報告されている ${ }^{6)}$.

また多くの症例が透析中またはその直後にからみが増 悪する。さらに就寝時に悪化する症例も多い7).かゆみの 起こり方は発作性であり，広い範囲に沉発するがそのな かでも背部に好発卞る。時には部分的に四肢の伸側, 頭, 耳孔や耳後部に起こる例もある。しかも，瘙痒感はイラ イラ感や不眠を二次的に生じ，患者にとうては悩み多い 合併症となる。

透析施行中の慢性腎不全のかゆみは腎機能検查の個久 の值とは相関せず，現況では発生原因が明らかにされて いない。しかし，副甲状腺機能充進，Ca の代謝異常が重 要視されている，副甲状腺摘出を行うとか内み証消失す るという報告もある ${ }^{8)}$.一方，副甲状腺切除でもかゆみの
表 6 痊痒感に対する現行の治療法

(1)抗ヒスタミン薬の内服

(2) ステロイド軟膏，尿素軟膏の外用

(3)へパリンの静注

(4) リドカインの静注

(5) 紫外線療法

(6) 活性炭の内服

(7) NSP $の$ 静注 $^{12)}$

(8) 自律神経調整剂 ${ }^{13)}$

止まらない場合も少なくない齐という。本センターでは $\mathrm{PTH}, \mathrm{Ca}, \mathrm{P}$ と瘙痒感の関係は認めていない。

透析患者では皮膚の発汗作用が衰えるとともに，皮脂 腺抢よび汗腺の機能が低下する結果，皮膚が脱水状況と なり毒性物質の排出が不十分となり痒みを起こす物質が 残留する結果として, 痒みが生じる可能性もある ${ }^{10)}$ 。ま た，透析患者の皮膚では肥満細胞の増加が認められ，そ の脱顆粒によってヒスタミンが遊離され，か仂みを生ず るという意見もある ${ }^{11)}$.

このように極めて高頻度に発生する透析症例のか加 の原因は，今日もなお一元的に説明できず，その治療法 も確立されていない。現行の治療法を表 6 に示す。

以上の上うに痒みの原因と考えられる病因がはっきり と解明されていないため，現状では薬物による治療は定 式化されていない。このような不快な症状に悩まされて いる患者が心理的平衡を乱されていることを考元ると， 我々はこの問題を解決するため，より効果的な薬物治療 法を研究しなければならない。痒みの症状学的治療にテ ルフェナジンを選ぶのが啇切であると我々が判断したの は，この薬物が主に胆汁排泄で，耐性の発現が少ないか らであり，また副作用，とりわけ何種類かの抗七ス夕ミ ン剤を使用した際に普通にみられる，中枢神経系の副作 用 (不眠症，鎮静)を起こす率が少ないからであった ${ }^{1 \sim 4)}$ 。

本研究では，やや有効以上の有効率が $80 \%$ ，やや有用 以上の有用度は $80 \%$ と, 研究開始時の我々の予測よりよ い結果であった。慢性腎不全の維持透析症例の痒みに対 するテルフェナジンの検討は少なく，Russo ら ${ }^{10)}$ の報告 をみるのみである。2 2 例の患者に $120 \mathrm{mg}$ を分 2 投与し， 20 日間，二重盲検法によって投与した結果，副作用や臨 床検查值異常は示さず，25 例中 20 例 $(80 \%)$ に効果が あったと高い有効率を報告している。

治療した患者の大半において，テルフェナジンが有用 であった事実 $(80 \%)$ と，IgE に関して投与前後での変 動がなかったところを見ると，IgE を仲介としたもので はないが，皮膚局所に扔けるヒスタミン依存性のメカニ ズムが存在するのではないかと我々は考えている。

透析症例, CAPD 症例でのテルフェナジン薬物動態を 
$60 \mathrm{mg}$ 経口単回投与によるカルボン酸型代謝物の推移に より考察する。 $60 \mathrm{mg}$ 経口単回投与時の $\mathrm{t}_{1 / 2}$ が健康男子 $(\mathrm{n}=7)$ で 3.4 時間であるのに比し, 透析症例で 5.1 時 間, CAPD 症例で 6.7 時間と,より緩徐に排泄されてい るものと思われる。 $\mathrm{t}_{\max }$ も健康男子の 2.3 時間に比し， 透析症例で 3.4 時間, CAPD 症例で 6.2 時間と遅延す る。その結果, $\mathrm{C}_{\max }$ が健康男子の $300 \mathrm{ng} / \mathrm{m}$ lに比し, 透析症例で $654 \mathrm{ng} / \mathrm{m} l, \mathrm{CAPD}$ 症例で $509 \mathrm{ng} / \mathrm{m} l$ と高值 を示すこととなる。 $\mathrm{AUC}_{0 \sim 24}$ も健康男子の $1,970 \mathrm{ng} ・ \mathrm{hr} /$ $\mathrm{m} l$ に比し, 透析症例で $6,917 \mathrm{ng} \cdot \mathrm{hr} / \mathrm{m} l, \mathrm{CAPD}$ 症例で $6,767 \mathrm{ng} \cdot \mathrm{hr} / \mathrm{m} l$ と高值を示すこととなる。

今回検討した症例は，テルフェナジンの主たる代謝臓 器である肝に障害を有しない慢性腎不全を選んである が，透析症例 CAPD 症例とも50 歳以上 (CAPD 症例の 1 例を除き) と高年齢であり，加齢による代謝遅延が $\mathrm{t}_{1 / 2}$ を延長させた可能性も否定できない。しかし，テルフェ ナジンは尿中に排泄されないが，そのカルボン酸型代謝 物 $\left(\mathrm{M}_{1}, \mathrm{MDL}-16455\right)$ 尿中総排泄率が約 30\%あるとの 報告（安藤和子, Personal communication, 1987） があ る。つまり $t_{1 / 2}$ の延長は，慢性腎不全における普遍的な 現象であろうと考えている。反復投与により AUCはさ らに高值を示すであろう。

一方透析患者では痒みが入浴後入床時に顕著に増悪す る症例が多い. 以上より臨床においては 1 日 1 回夕食後 $60 \mathrm{mg}$ 投与が至適投与法ではないかと考光ている。

本研究の結果は，テルフエナジンが特に中枢系に関連 しての副作用がない，あるいはほとんどそれがない上に， 高い治療効果を持っており，これまで使用されてきた対 症治療法に代わって用い得る有効加つ確実な, そして代 表的な対策であることを示している。

ただしここの種の薬物の効果は長期にわたって評価し なければならない。

\section{まとめ}

慢性腎不全のため透析を施行している症例で, 瘙痒感 を訴えている 20 例 (男 6 例，女 14 例，平均年歯 $58 \pm 13$ 歳, 平均透析年数 $3.2 \pm 2.5$ 年)に対し, テルフェナジン $120 \mathrm{mg} /$ 日分 2 を 週間投与し, 投与前後で痖㾕感, $\mathrm{IgE}$ に関して検討した。

1。瘁痒感は有意 $(\mathrm{p}<0.001)$ に改善した。有効率 $80 \%$ ，安全度 $100 \%$ ，有用度 $80 \%$ であった。 IgE は有意 な変動を認めなかった。

2。透析症例における非透析日のカルボン酸型代謝物 の $\mathrm{C}_{\max }$ は $654.4 \pm 250.6 \mathrm{ng} / \mathrm{m} l, \mathrm{t}_{\max } 3.4 \pm 0.5$ 時間, $\mathrm{t}_{1 / 2}$ $5.1 \pm 1.6$ 時間, $\mathrm{AUC}_{0 \sim 24} 6,917 \pm 3,519 \mathrm{ng} \cdot \mathrm{hr} / \mathrm{m} l$ であった。

3。透析症例における透析日のカルボン酸型代謝物の $\mathrm{C}_{\max }$ は $670.5 \pm 124.5 \mathrm{ng} / \mathrm{m} l, \mathrm{t}_{\max } 4.3 \pm 0.2$ 時間, $\mathrm{t}_{1 / 2}$
$5.8 \pm 0.8$ 時間, $\mathrm{AUC}_{0 \sim 24} 7,421 \pm 2,236 \mathrm{ng} \cdot \mathrm{hr} / \mathrm{m} l$ であった。 透析によるテルフェナジンクリアランスは $20 \mathrm{ml} / \mathrm{min}$ であった。

4.CAPD症例におけるカルボン酸型代謝産物の $\mathrm{C}_{\max }$ は $508.9 \pm 60.2 \mathrm{ng} / \mathrm{m} l, \mathrm{t}_{\max } 6.2 \pm 1.5$ 時間, $\mathrm{t}_{1 / 2} 6.7 \pm 0.6$ 時 間， $\mathrm{AUC}_{0 \sim 24} 6,767 \pm 171 \mathrm{ng} \cdot \mathrm{hr} / \mathrm{m} l$ であった。

以上の結果により抗アレルギー剂テルフェナジン（ト リルダン®）は，透析症例の皮膚痹痒感に対しても有用 であると示晙された。

\section{文献}

1) Cheng $\mathrm{HC}$, Woodward JK: A Kinetics study of the antihistaminic effect of terfenadine. Arzneimittelforsch $32: 1160-1166,1982$

2) Nicholson AN : Antihistaminic activity and central effects of terfenadine. A review of european studies. Arzneimittelforsch 32 : 1191-1193, 1982

3) Wiech NL, Martin JS : Absence of an effect of terfenadine on Guinea pig brain histamine $\mathrm{H}_{1}-$ receptors in vivo determined by receptor binding techniques. Arzneimittelforsch 32(2)9A : 1167 $-1170,1982$

4) Woodward JK, Munro NL : Terfenadine, the first non-sedating antihistamine. Arzneimitterlforsch 32 : 1154-1156, 1982

5) Gastpar H, Dieterich HA : Prophylaxis of seasonal allergic rhinitis with a new antihistaminic drug. Arzneimittelforsc $32: 1209-1211,1982$

6) Tapia L, Cheigh JS, David DS, Sullivan JP, Saal S, Reidenberg MM, Stenzel HK, Rubin AL : Pruritus in dialysis patients treated with parenteral lidocaine. N Engl J Med 296 : 261-262, 1977

7) Rosen $T$ : Uraemic pruritus : a review. Cutis 23 : 790-792, 1979

8) Hampers CL, Katz AI, Wilson RE, Merrill JP : Disappearance of "uremic" itching after subtotal parathyroidectomy. N Engl J Med 279 : 695-697, 1968

9)西山茂夫：皮膚異常一かゆみ。臨床透析 2 : 146-147, 1986

10) Russo GE, Spaziani M, Guidotti $C$, Scarpellini MG, Leri O, Bonini S, Crisciotti C, Carmenini G : Il pruritonegli uremici cronici in emodialisi periodica. Min Urol Nefr $38: 443-447,1986$

11) Neiman RS, Bischel MD, Lukes RJ : Uremia and mast-cell proliferation. Lancet $\mathrm{i}$ : 959, 1972 
12）石黒源之, 平野高弘, 幾高敏晴, 林 俊明, 那須 浩, 森本勝男, 平野喜美子, 平野恭弘, 岩田 靖, 白木 信一郎：透析患者の皮膚搔㾕症に対するノイロトロ ピン大量療法の効果。基礎と臨床 $20 ： 8321-8323$, 1986
13）石黒源之，平野高弘，幾高敏晴，那須 浩，森本勝 男, 三輪陽子, 高田信幸, 森 典子, 渡辺一敏, 森 甫, 渡辺佐知郎: 透析患者の自律神経機能障害と皮 膚搔痒症に対する Tofisopam の効果，臨床透析 $14: 1783-1789,1988$ 